\title{
飛翔体誘導制御系における目標追尾装置の動特性モデル*1 \\ Dynamic Models of Target Trackers in Guided Vehicles
}

\author{
江 口弘 文*2 - 山 忠*3 \\ Hirofumi EGuCHI and Tadashi YaMASHITA
}

Key Words : Guided Vehicle, Target Tracker, Strapdown Tracker

\begin{abstract}
A homing missile which is guided by the laws such as the proportional navigation guidance, the argumented proportional navigation guidance, and the optimal guidance has a target tracker to detect the line-of-sight rate, which is essentially needed for these guidance laws. Three different types of the tracker are used for this purpose; The first is the free-gyro gimbaled tracker; the second is the rategyro gimbaled tracker; the third is the strapdown type tracker. In this paper, basic dynamic models of these trackers are given at first, and then unstructured model uncertainty of these trackers are discus. sed. And the imperfect tracker stabilization is defined from the standpoint of the tracker model uncertainty, which is the important information for the robust design of the missile guidance system. By using this definition, it is shown that the stabilization loop gain of the rate-gyro gimbaled tracker and the sample frame time of the strapdown type tracker correspond each other.
\end{abstract}

\section{1.まえがき}

比例航法" ${ }^{1)}$, 改良比例航法 ${ }^{21}$, 最適航法 ${ }^{3)}$ 等に基づい て制御される飛翔体は，いずれも慣性空間における目 視線角（目標と飛翔体の重心位置を結ぶ直線が空間に おけるある基準線となす角）の変化率を計測するため の目標追尾装置を搭載しており，この目視線角の変化 率はこれらの航法に基づいた誘導制御系を構成する場 合の基本入力になるものである4-6) しかしながら， この目標追尾装置は飛翔体という高速運動体に搭載さ れた状態で機能しなければならないため，飛翔体運動 との連成の影響（空間安定特性の不完全性という）に よる誤差成分を出力信号に含み，誘導制御系全体を不

\footnotetext{
*1 平成元年 4 月 4 日, 日本航空宇宙学会第 20 期年会および 講演会で椌。平成元年 7 月 20 日原稿受理

*2 防衙庁技術研究本部第 3 研究所

*3 九州工業大学工学部制御工学科
}

安定にしてしまうことがある ${ }^{7,8)}$. したがって飛制体 の誘導制御系の設計に当たっては，目標追尾装置の空 間安定特性に関するモデル不確定性を考慮にいれた口 バスト設計が重要であり，そのためには飛翔体運動と の連成を考慮に入れた目標追尾装置の動特性モデルの 検討，および空間安定特性に関する定量的考察が不可 欠である。

この目標追尾装置については，Rue, White らが詳

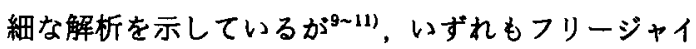
口を用いた装置についての解析であり．また誘導制御 系という立場からの考察がなされていない. Nesline らはレートジャイロを用いて構成された目標追尾装置 について，空間安定特性の不完全性と誘導制御系の安 定性の関係について述へているが，空間安定特性の不 完全性を表す定量的定義式が示されていない票。 た目標追尾装置の新しい形態として最近注目を集めて

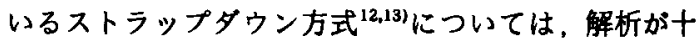
分なされていない。

本論文ではまず、誘導制御問題における目標追尾装 置の立場を説明したのち，この装置を，1）フリージ ヤイロ方式，2）レートジャイロ方式，3）ストラッフ ダウン方式の 3 方式に分類し，各々について飛翔体運 動との連成を考虑に入れた動特性モデルを与える．次 に，誘導制御問題から捉えた場合の目標追尾装置の一 般的モデル不確定性の定式化には 2 種類の考え方が必 要であることを示し，このモデル不確定性の一つの原 因である空間安定特性の不完全性については定量化の ための定義式を与える．最後に 3 方式について動特性 モデルによる特性解析を示し，基本的特性を明確にす るとともに,レートジャイロ方式の空間安定化ルーフ ゲインの逆数とストラップダウン方式のサンプルフレ 一ムタイムとが，空間安定特性という意味において一 対一に対応していることを示す。

これらの解析により従来基本的解析が示されていな かったストラップダウン方式も含めて, 目標追尾装置 
の各方式における特徴が定量的に明確にされる。また ここて与えた空間安定特性の不完全性に関する定義式 は、実際に完成された目標追尾装置の性能产価の尺度 としても使用可能であることを示す

\section{2. 誘導制御問題}

飛㓞体の誘導制御問題とは，三次元空間において飛 翔体と目標を会合させるための飛翔体の制御問題であ り，時刻 $t$ における飛翔体および目標の位置べトル を $X_{\mathrm{M}}(t), X_{\mathrm{T}}(t)$ とするとき，ある適当な時刻 $t_{\mathrm{f}} お よ$ び許容誤差 $\varepsilon_{\mathrm{m}}$ に対して,

$$
\left\|X_{\mathrm{M}}\left(t_{\mathrm{r}}\right)-X_{\mathrm{T}}\left(t_{\mathrm{f}}\right)\right\|<\varepsilon_{\mathrm{m}}
$$

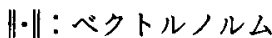

を満足させることである．飛翔体はロール軸に関する 運動について十分制御されているとして，ピッチ軸と ヨー軸に関するカップリングを無視して二次元平面て の問題として捉えた場合の概念を第 1 図に示す。第 1 図は時刻 $t=0 に お け る$ 飛翔体と目標を結んだ直線を 基準の目視線（Line-of-Sight，図中では L.O.S.と略 記している)としており，その目視線に対する飛翔体 と目標の経路角がそれぞれ $\Psi_{\mathrm{M}}, \Psi_{\mathrm{T}}$ ，速度べクトルが $\boldsymbol{V}_{\mathrm{M}}, \boldsymbol{V}_{\mathrm{T}}$ ，基準目視線に直交する方向の加速度ベクト ルが $n_{\mathrm{M}}, \boldsymbol{n}_{\mathrm{T}}$ であり， $\boldsymbol{a}_{\mathrm{M}}$ は $\boldsymbol{V}_{\mathrm{M}}$ に直交する飛制体の加 速度べクトルである．また $\sigma(t)$ は目視線角， $V_{\mathrm{c}}$ は相 対接近速度， $t_{\mathrm{g} 0}$ は会合までの時間， $e(t)$ は基準目視 線に直交方向の距離誤差である。

第 1 図において飛翔体の加速度を制御するための指 令加速度 $a_{\mathrm{c}}$ は，たとえば比例航法の場合， $N^{\prime}$ を航法 定数として,

$$
a_{\mathrm{c}}=N^{\prime} V_{\mathrm{c}} \dot{\sigma}
$$

で与えられる ${ }^{1,6)}$.したがって目標追尾装置は目視線 角の変化率 $\dot{\sigma}$ を計測することが義務づけられている． また改良比例航法，最適航法等においても $a_{\mathrm{c}}$ を決定

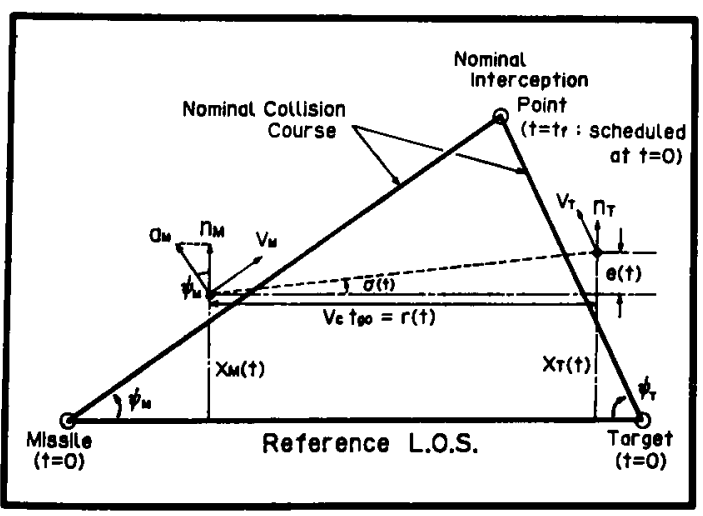

第 1 図 誘導制御問題の幾何学的概念
する制御則で目視線角の変化率が必要とされる

\section{3. 飛翔体運動との連成を考虑にいれた目標追尾装置 の動特性モデル}

二次元平面の運動に限定した場合の目標追尾装置に 関する座標軸関係を第 2 図に示す．第 2 図において， $X, Y$ 軸は慣性空間に固定した座標系, $X_{\mathrm{M}}, Y_{\mathrm{M}}$ 軸は 飛叛体に固定した運動座標系， $X_{\mathrm{s}}$ 軸はトラッカアン テナ（以下単にアンテナという）のアンテナ軸方向で あり，初期状態では $X_{\mathrm{M}}, Y_{\mathrm{M}}$ 軸は $X, Y$ 軸に一致して いる。また $\sigma$ は目視線角であり，ここでは近似的に 飛磁体の重心位置とアンテナの重心位置は一致してい るとしている， $\theta$ は飛翔体の回転運動によって発生す るオイラー角，入は飛翔体の機軸方向とアンテナ軸方 向とがなす首振角，而は飛翔体に固定した座標系で みた目視線角， $\varepsilon$ は目標方向とアンテナ軸方向とがな す誤差角である。

目標追尾装置はいずれの方式においても、この誤差 角 $\varepsilon$ を検出し， $\varepsilon$ が零になるように絶えずアンテナ軸 $X_{\mathrm{s}}$ を目標方向に指向させることにより目標追尾を実 現している4 $X_{\mathrm{s}}$ 軸は目標を追尾するという意味にお いてのみ慣性空間 $X Y$ 平面内で運動するものであり， 飛翔体自身に発生する回転運動によって動いてはいけ ない. $X_{\mathrm{s}}$ 軸のこの慣性空間における自立性を目標追 尾装置の空間安定特性という”。なお以下において は，とくに誤解のおそれがない場合は空間安定特性の 不完全性という意味においても単に空間安定特性とい j。

空間安定特性の物理的実現方法の相違によって，目 標追尾装置は次の 3 方式に大別できる．すなわち，1） アンテナ自身を高速で回転させることによるジャイロ 剛性でスピン軸にあたる $X_{\mathrm{s}}$ 軸を慣性空間に安定させ る(フリージャイロ方式），2）アンテナを支持するジ ンバル軸にレートジャイロを搭載し， $X_{\mathrm{s}}$ 軸を慣性空

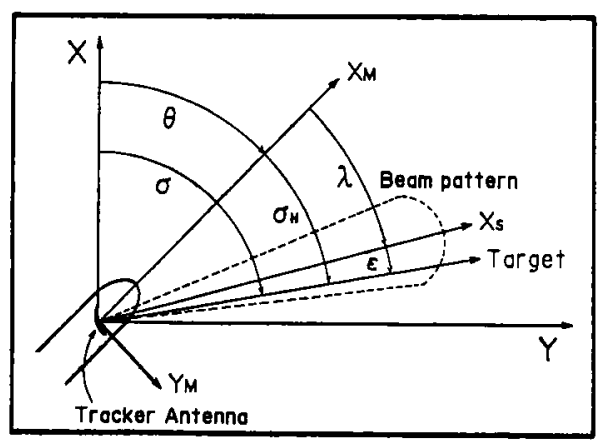

第 2 図 目標追尾装置の座標軸関係 
間に自立させるための制御系を構成する(レートジャ イロ方式，3）アンテナ自身は飛玤体に直接固定し， アンテナから照射する電波の方向を電気的に直接制御 する (ストラップダウン方式)，の 3 方式である.

これら 3 方式いずれの場合においても，第 2 図で，

$$
\begin{aligned}
& \sigma_{\mathrm{H}}=\sigma-\theta \\
& \varepsilon=\sigma_{\mathrm{H}}-\lambda
\end{aligned}
$$

という幾何学的関保が成立する. 目標追尾装置の出力 $X_{0}$ としては一般に

$$
X_{0}=K_{\mathrm{H}} \varepsilon
$$

が用いられる゙．ここで $K_{\mathrm{H}}$ はトラッカゲインである。 また出力 $X_{0}$ は $X_{\mathrm{s}}$ 軸を目標方向へ追尾させるための トルカ入カとなり目標追尾装置としてのフィードバッ クループが構成される.トルカ出力 $T_{\mathrm{q}}$ は、トルカゲ インを $K_{\mathrm{T}}$ とし, トルカの動特性を 1 とすると，

$$
T_{\mathrm{a}}=K_{\mathrm{T}} X_{0}
$$

\section{である゙).}

前記 3 方式において異なるのはトルカ出力に対する アンテナの運動力学であり.フリージャイロ方式の場 合は最も簡略化された運動方程式として，

$$
H \ddot{\lambda}=T_{\mathbf{q}}
$$

で表現される ${ }^{10)}$.ここで $H$ はアンテナの角運動量, 入'はプリセッション運動によって発生する首振角で あり，第 2 図における首振角 $\lambda$ とは，

$$
\lambda=\lambda-\theta
$$

の関係がある. $\theta$ が零のとき $\lambda$ と致する。 ( 3 ) ( 8 )式を用いて, フリージャイロ方式の動特性 モデルを第 3 図に示す

次にレートジャイロ方式の場合は、ジンバル軸回り のアンテナの運動は。

$$
\ddot{\lambda}=T_{\mathbf{q}}
$$

で表現される。ここではアンテナのジンバル軸回 り慣性能率、入は首振角である。また(9)式によって

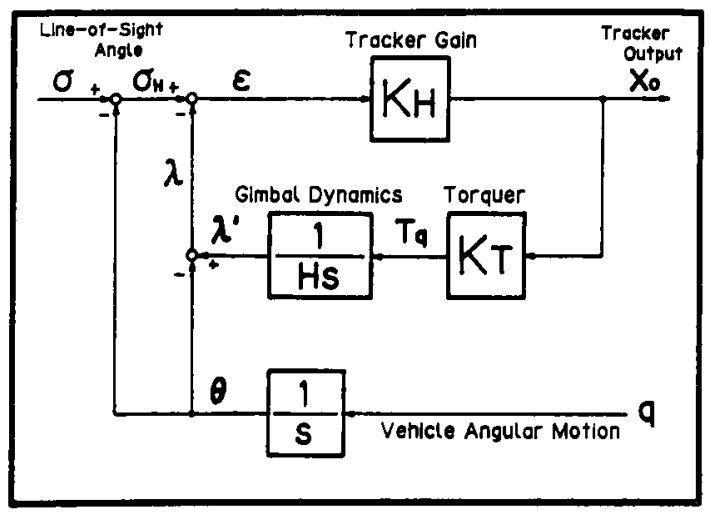

第 3 図 フリージャイロ方式目標追尾装置の動特性モデル
発生するジンバルフレームの回転角速度文および飛 翔体に発生する回転角速度 $q$ はともに、ジンパルフ レームに搭載されたレートジャイロによって検出さ れ，空間安定化のためのトルカにフィードバックされ る.したがって(6)式は。

$$
T_{\mathrm{q}}=K_{\mathrm{T}}\left(X_{0}-\dot{\lambda}-q\right)
$$

となる．（3)〜(5)，(9)〜(10)式を用いてレートシ ヤイロ方式の動特性モデルを第 4 図に示す.

ストラップダウン方式においては，ジンバルの力学 的運動によってではなく、アンテナから照射する電波

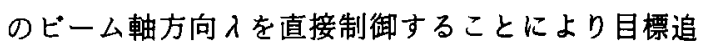
尾を実現する。このとき入角の補正は，目標と飛翔 体との相対位置関係の変化によって発生する誤差角

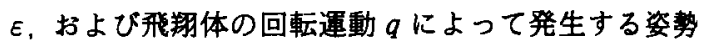
角 $\theta$ の両者に対してなされなければならない。また， 誤差角 $\varepsilon$ に対しては第 3 図から類推できるように。 目視線角に对して基本的には微分回路が構成されてい なければならないため，数学的な積分回路を通して電 波ビーム角入の制御に用いられる，以上のことを考

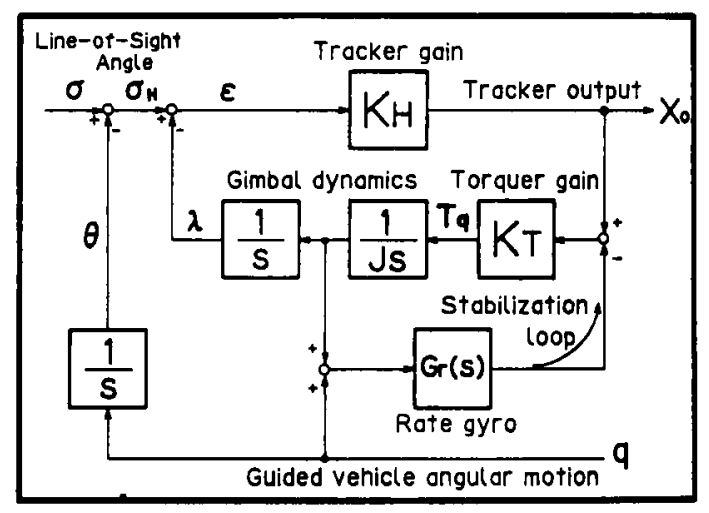

第 4 図レートジャイロ方式目標迫尾装置の轩特性モデル

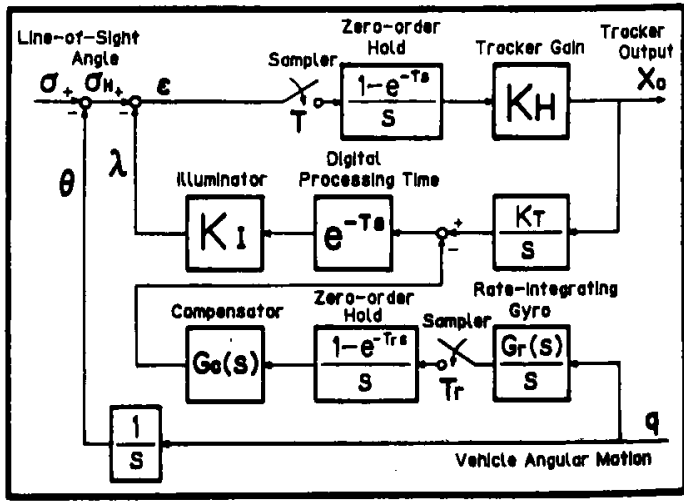

第 5 図 ストラッブダウシカ式目標追尾装需の特性 モデル 
虑にいれて、ストラップダウン方式の動特性モデルを 第 5 図に示す.

第 5 図て $K_{1}$ は電波照射についての首振角特性を示 しており、本文では 1 としている．また前向きループ のサンプラと零次ホールドは信号処理のためのもので あり、Tはサンプルフレームタイムを表している。 さらにフィードバックループの無駄時間 $e^{-T S}$ は, 詒 差角 $\varepsilon$ および姿勢角 $\theta$ の補正に要する遅れであり， これはサンプルフレームタイム $T$ に等しい。 また $T_{r}$ は飛翊体の姿勢角に関するレート積分ジャイロ出力の サンプルフレームタイムであり、ジャイロ動特性 $G_{\mathrm{r}}(s)$ および補償器 $G_{\mathrm{c}}(s)$ は本文では 1 としている.

\section{4. 目樰追尾装置のモデル不確定性}

第 3 図〜第 5 図加ら目標追尾装置の出力 $X_{0}$ は一般 にラプラス変換を用いて，

$$
X_{0}(s)=G_{\mathrm{H}}(s) \sigma(s)+G_{\mathrm{q}}(s) q(s)
$$

である。ここで $G_{H}(s)$ は目視線角 $\sigma に$ 対する目標追 尾装置の伝達関数であり， $G_{9}(s)$ は飛翔体の回転角速 度 $q$ によって生じる出力の伝達関数，すなわち目標 追尾装置の空間安定特性の不完全性を表している。

ここで第 3 図〜第 5 図において，たとえばトラッカ ゲイン $K_{\mathrm{H}}$ が誤差角 $\varepsilon$ に対して $\varepsilon$ が大きい領域で変化 し、その結果目標追尾装置出力が基準状態から変動す ることを考慮に入れるど，

$$
G_{\mathrm{H}}(s)=\left(1+\Delta_{\mathrm{H}}(s)\right) G_{\mathrm{HO}}(s)
$$

と考えられる.ここで $G_{\mathrm{H} 0}(s)$ は䛊差角 $\varepsilon$ が塞度近傍 での目視線角に対する基準の伝達関数であり， $\Delta_{\mathrm{H}}(s)$ はそれからの変動成分を表す.

また第 3 図，第 4 図では，目標追尾装置に対する飛 㓞体運動の影響が基本的な場合についてモデル化され ているが、たとえばジンバルベアリングに発生する摩 擦卜ルク等を考虑に入れると、基本モデルからの特性 変動が考えられる10) また第 5 図における $K_{1}$ も、ド

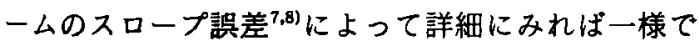
はない. したがって第 3 図〜第 5 図の基本モデルにこ れらの変動要因を考虑に入れると，

$$
G_{\mathrm{q}}(s)=G_{\mathrm{q} 0}(s)+\Delta G_{\mathrm{q}}(s)
$$

と考える必要がある．ここで $G_{90}(s)$ は基本モデルで の飛叛体回転角速度に対する伝達関数であり， $\Delta G_{\mathrm{q}}(s)$ はその変動成分を表す。なお,フリージャイ 口方式の場合は $G_{q 0}(s)$ が零になるため ((16) 式参照)， (12)式とは異なり (13) 式についてはモデル不確定性を 和の形で表現している．また 5 章の解析では $\Delta_{\mathrm{H}}(s)$, $\Delta G_{q}(s)$ はいずれも零としている.

目標追尾装置に対して，(12)，(13)式のモデル不確 定性を考虑に入れた場合の誘導制御系のブロック線図

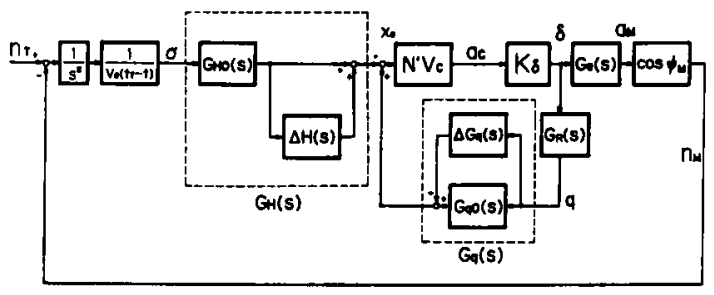

第6図 誘導制御系における目標追尾装置のモテル不確 定性

を第 6 図に示す，第 6 図で目標追尾装置のモデル不確 定性を除いた部分は, Nesline らが誘導制御系の解析 に用いているブロック線図と同じである ${ }^{7,8)}$ 第 6 図 で， $G_{\mathrm{a}}(s)$ は舵角 $\delta$ に対する飛翔体旋回加速度 $a_{\mathrm{M}}$ ま での伝達関数， $G_{\mathrm{R}}(s)$ は回転角速度 $q$ までの伝達関数 を示している．第 6 図において， $\Delta_{H}(s)$ は，たとえば Doyle らが取り扱っている制御系のモデル不確定性で あり、誘導制御系においてループゲインの変動という

影響をもたらす

しかしながら $G_{9}(s)$ の存在は第 6 図に示したよう に、誘導制御系の中に寄生ループを構成し，この奇生 ループは誘導制御系全体を不安定にしてしまうことが あることが知られている ${ }^{7,8)}$. 目標追尾装置の出力信 号が理想的にはすであるべきとする航法上の要求か ら考えれば， $G_{9}(s)$ の存在自身も理想モデルからの変 動成分と見なすことができる。この種の寄生ループを 構成するモデル不確定性はその要因と影響が複雑であ り，誘導制御系設計上の一般的取扱いは困難である。 飛翔体の分野においては筆者らが寄生ループの安定解 析と誘導制御系のシミェレーションを併用した一手法 を述べているにすぎない ${ }^{15)}$.

この $G_{q}(s)$ は，目標追尾装置の空間安定特性の不完 全性によって生じるものである.そこでこのモデル不 確定性を定量的に表現するために空間安定特性を以下 のように定義する。

〈定義〉「飛翔体における目標追尾装置の空間安定 特性とは, 目標追尾装置出力に対する飛翔体回転角速 度の影響の程度をいい，その程度 $K_{\mathbf{s}}(\omega)$ を目視線角 の変化率が零のときの, 飛翔体の正弦波状回転角速度 に対する目標追尾装置出力の定常振幅の比の対数，す なわち(14)式で表す。

$$
K_{\mathbf{S}}(\omega)=\left.20 \log _{10} \frac{|X(\omega)|}{|q(\omega)|}\right|_{\dot{\sigma}=0}
$$

ここで $|q(\omega)|$ は入力正弦波の振幅, $|X(\omega)|$ は入力角 周波数に対応した出力の定常振幅を表す.」

この定義によると(11)式の場合は，

$$
K_{\mathrm{S}}(\omega)=20 \log _{10}\left|G_{\mathrm{q}}(j \omega)\right|
$$


である。（14）式の定義の特徵は空間安定特性をゲイン のみで定義したところにある．すなわち(13)式で表現 されるモデル不確定性が解析的に明らかでない場合て も，つまり系をブラックボックスとする場合にも，実 験的手法によって $|X(\omega)| /|q(\omega)|$ を求めることにより $K_{\mathrm{S}}(\omega)$ を知ることが可能であり，その特性を誘導制御 系の設計，あるいは目標追尾装置の性能比較，評価に 活用することができる。

\section{5. 特 性 解 析}

5.1 フリージャイロ方式 第 3 図からフリージャ イロ方式の出力信号 $X_{0}$ はラプラス変換を用いて,

$$
\begin{aligned}
& X_{0}(s)=\frac{K}{T_{\mathrm{c}} s+1} s \sigma(s) \\
& \text { ただし, } T_{\mathrm{c}}=H / K_{\mathrm{H}} K_{\mathrm{T}}, K=H / K_{\mathrm{T}} \text { である. }
\end{aligned}
$$

(16)式からフリージャイロ方式の出力信号は $s \sigma(s)$ す なわち $\dot{\sigma}(t)$ を1次遅れで出力しており。その帯域は $\omega_{\mathrm{c}}=1 / T_{\mathrm{c}}$ で与えられる。 また(16)式からわかるよう に $G_{\mathrm{qo}}(s)$ は零である。このとき誤差角 $\varepsilon$ は，

$$
\varepsilon(s)=\frac{T_{c}}{T_{\mathrm{c}} s+1} s \sigma(s)
$$

であり、ランプ関数状の目視線角に対して定常偏差が 残る制御系である.したがってアンテナの視野角の最 大值を $\varepsilon_{\max }$ とすると追尾が維持される条件は，

$$
|\varepsilon(t)| \leq \varepsilon_{\max }
$$

で表すことができる。

いま $\sigma(t)=A t$ とすると, 誤差角の定常值 $\varepsilon_{\mathrm{s}}$ は

$$
\varepsilon_{\mathrm{s}}=\lim _{s \rightarrow 0} s \varepsilon(s)=A T_{\mathrm{c}}
$$

である.したがって(18)式は，

$$
\left|A T_{\mathrm{c}}\right| \leq \varepsilon_{\max }
$$

であり。(20)式が満足される $A$ の最大値がこの装置 の最大追尾角速度 $\dot{\lambda}_{\max }{ }^{\prime}$ を表すから，

$$
\dot{\lambda}_{\max }{ }^{\prime}=\varepsilon_{\max } \cdot K_{\mathrm{H}} K_{\mathrm{T}} / H
$$

である。ここでトルのの最大出カトルクを $T_{\text {Mmax }}$ で 表すと，

$$
\varepsilon_{\max } \cdot K_{\mathrm{H}} K_{\mathrm{T}} \leq T_{\mathrm{Mmax}}
$$

\section{という制限があることがわかる。}

5.2 レートジャイロ方式 第 4 図からレートジャ イロ方式の出力信号 $X_{0}$ はレートジャイロ自身の動特 性を 1 とすると。

$$
\begin{aligned}
X_{0}(s)= & \frac{K_{\mathrm{H}}\left(J_{s}+K_{\mathrm{T}}\right)}{J s^{2}+K_{\mathrm{T}} s+K_{\mathrm{T}} K_{\mathrm{H}}} s \sigma(s) \\
& -\frac{K_{\mathrm{H}} J s}{J s^{2}+K_{\mathrm{T}} s+K_{\mathrm{T}} K_{\mathrm{H}}} q(s)
\end{aligned}
$$

であり，誤差角 $\varepsilon$ は

$$
\varepsilon(s)=\frac{1}{K_{\mathrm{H}}} X_{0}(s)
$$

で与えられる。(23)式第 1 項が，比例航法を表現する ために必要な目視線角の変化率を計測している項であ り，第 2 項はレートジャイロ方式の空間安定特性を示 している.いま $q(t)=0$ のとき，(23)式から目視線角 の変化率に对する出力ゲインを $\omega S \sqrt{K_{\mathrm{T}} K_{\mathrm{H}} / J}$ 域で一 定に保つためには，KT $/ J$ を $K_{\mathrm{SL}}$ とおけは， $K_{\mathrm{SL}}>$ $\sqrt{K_{\mathrm{SL}} K_{\mathrm{H}}}$ すなわち，

$$
K_{\mathrm{sL}} \geqq K_{\mathrm{H}}
$$

でなければならない。ここで $K_{\mathrm{sL}}$ は第 4 図の空間安定 化ループのループゲインを表している．目標追尾装置 としての带域は， $\omega_{\mathrm{c}} \fallingdotseq \sqrt{K_{\mathrm{SL}} K_{\mathrm{H}}}$ で見積ることができ る.

次に，ランプ関数状の目視線角 $\sigma(t)=A t$ に対して $q(t)=0$ のとき，誤差角 $\varepsilon(t)$ の定常值 $\varepsilon_{\mathrm{s}}$ は，

$$
\varepsilon_{\mathrm{s}}=\lim _{s \rightarrow 0} s \varepsilon(s)=A / K_{\mathrm{H}}
$$

であり,フリージャイロ方式の場合と同様に一定の誤 差角で目標を追尾している．この場合も追尾が維持さ れる条件は(18)式により，

$$
\left|\frac{A}{K_{\mathrm{H}}}\right| \leq \varepsilon_{\max }
$$

である。したがってレートジャイロ方式の最大追尾角 速度 $\dot{\lambda}_{\max }$ は。

$$
\dot{\lambda}_{\max }=\varepsilon_{\max } \cdot K_{\mathrm{H}}
$$

で与えられ，フリージャイロ方式と異なって，トルカ のゲイン $K_{\mathrm{T}}$ は直接には最大追尾角速度の向上に寄与 していない。しかし(25)式により，レートジャイロ方 式の場合も目標追尾性能はトルカゲインで拘束される ことがわかる.

空間安定特性：(14)式の定義によればレートジャ1 口方式の空間安定特性は (23) 式から，

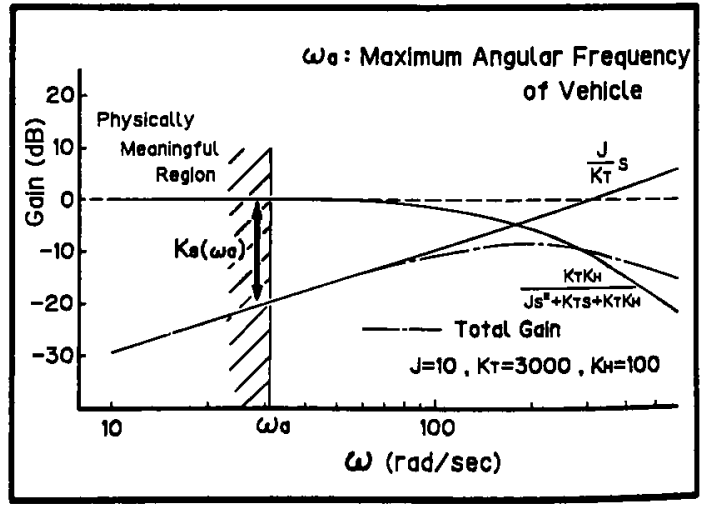

第 7 図 レートジャイロ方式目骦道尾装管空間安定特性げ イン線図 


$$
K_{\mathrm{S}}(\omega)=20 \log \frac{J K_{\mathrm{H}} \omega}{\sqrt{\left(K_{\mathrm{T}} K_{\mathrm{H}}-J \omega^{2}\right)^{2}+K_{\mathrm{T}}^{2} \omega^{2}}}
$$

で与えられる。第 7 図に $J=10, K_{\mathrm{T}}=3,000, K_{\mathrm{H}}=100$ としたときの(29)式のゲイン線図を示す.第 7 図にお いて現実に考慮すべき領域は飛㓞体の固有角周波数の 最大值 $\omega_{\mathrm{a}}$ (小型の飛翔体では約 $30 \mathrm{rad} / \mathrm{s}$ 程度である) 以下の領域であり，その領域において(29)式は，

$$
K_{\mathrm{S}}(\omega) \fallingdotseq 20 \log \left|\omega / K_{\mathrm{SL}}\right|
$$

と近似することができる。このとき $K_{\mathrm{s}}\left(\omega_{\mathrm{a}}\right)$ が誘導制 御系設計上許容されうる值 $K_{\mathrm{s}}^{*}\left(\omega_{\mathrm{a}}\right)$ 以下になるように $J お よ ひ ゙ K_{\mathrm{T}}$ が選定されなければならない． $K_{\mathrm{S}}^{*}\left(\omega_{\mathrm{a}}\right)$ 決定法の一例は文献 15 に述へている.

5.3 ストラップダウン方式 第 5 図で目標追尾系 の開ループ伝達関数 $G_{\mathrm{OL}}(s)$ は,

$$
G_{\mathrm{OL}}(s)=\frac{K_{\mathrm{H}} K_{\mathrm{I}} K_{\mathrm{T}} e^{-T s}\left(1-e^{-T s}\right)}{s^{2}}
$$

でり，前向き伝達関数 $G_{\mathrm{FL}}(s)$ は，

$$
G_{\mathrm{FL}}(s)=\frac{K_{\mathrm{H}}\left(1-e^{-T s}\right)}{s}
$$

である。また追尾系の閉ループ伝達関数 $W(s)$ は，

$$
W(s)=\frac{G_{\mathrm{FL}}(s)}{1+G_{\mathrm{OL}}(s)}
$$

である。このとき，目視線角に対する誤差角 $\varepsilon(s)$ は，

$$
\varepsilon(s)=\frac{1}{1+G_{0 L}(s)} \sigma(s)
$$

である。また外乱 $q(s)$ については，一般にレート積 分ジャイロ出力のサンプルフレームタイム $T_{\mathrm{r}}$ が. 追 尾ループのサンプルフレームタイム $T$ に比へて十分 小さいことから連続信号とみなすと，

$$
G_{\mathrm{s}}(s) q(s)=\left(K_{\mathrm{l}} e^{-r s}-1\right) \frac{1}{s} q(s)
$$

が第 5 図の入力点で加算されているのと同等である.

したがって目標追尾装置出力は，

$$
\begin{aligned}
X_{0}(s)= & W(s) \sigma(s) \\
& +W(s) G_{\mathrm{s}}(s) q(s)
\end{aligned}
$$

と考えることができる.

$G_{\mathrm{OL}}(s), G_{\mathrm{FL}}(s) の Z$ 変換は，一般に関数の $Z$ 変換を Z[・]で表すと,

$$
\begin{aligned}
& =\frac{K_{\mathrm{H}} K_{\mathrm{I}} K_{\mathrm{T}} \cdot T \cdot z^{-z}}{\left(1-z^{-1}\right)} \\
G_{\mathrm{FL}}{ }^{*}(z) & =K_{\mathrm{H}}\left(1-z^{-1}\right) Z[1 / s] \\
& =K_{\mathrm{H}}
\end{aligned}
$$$$
G_{\mathrm{OL}}{ }^{*}(z)=K_{\mathrm{H}} K_{\mathrm{I}} K_{\mathrm{T}} z^{-1}\left(1-z^{-1}\right) Z\left[1 / s^{2}\right]
$$

である。したがって，目視線角に対するストラップダ ウン方式のパルス伝達関数 $W^{*}(z)$ は，

$$
W^{*}(z)=\frac{K_{\mathrm{H}}\left(1-z^{-1}\right)}{1-z^{-1}+K_{\mathrm{H}} K_{\mathrm{I}} K_{\mathrm{T}} \cdot T \cdot z^{-2}}
$$

であり

$$
\varepsilon^{*}(z)=\frac{\left(1-z^{-1}\right)}{1-z^{-1}+K_{\mathrm{H}} K_{1} K_{\mathrm{T}} \cdot T \cdot z^{-2}} \sigma^{*}(z)
$$

である。ここで $G_{0 L}{ }^{*}(z), G_{\mathrm{FL}}{ }^{*}(z), W^{*}(z), \varepsilon^{*}(z)$ はそ れぞれ $G_{\mathrm{OL}}(s), G_{\mathrm{FL}}(s), W(s), \varepsilon(s) の Z$ 変換を表す したがって周波数応答特性は，(39)式において $z=$ $e^{j \omega T}$ とおくことにより得られる. 第 8 図に $K_{\mathrm{I}}=K_{\mathrm{T}}=$ $1, K_{\mathrm{H}}=50$ でサンプルフレームタイム $T=1 \mathrm{~ms}$ とし た場合の結果を示す．第 8 図の特性は、フリージャイ 口方式，レートジャイロ方式の場合と同様に目視線角 $\sigma$ に対して近似微分特性を示している. 帯域として は，サンプルフレームタイム $T$ が十分小さいときは 連続系に近いことから $\omega_{\mathrm{c}} \fallingdotseq K_{\mathrm{H}} K_{1} K_{\mathrm{T}}$ と見積ることが できる。

次に,ランプ関数状の目視線角に対する愦差角につ いて考える． $\sigma(t)=A t$ のとき

$$
\sigma^{*}(z)=\frac{A T z^{-1}}{\left(1-z^{-1}\right)^{2}}
$$

だから，

$$
K_{\mathrm{L}}=K_{\mathrm{H}} K_{\mathrm{I}} K_{\mathrm{T}}
$$

とおくと(40)式から，

$$
\varepsilon^{*}(z)=\frac{A T z^{-1}}{\left(1-z^{-1}+K_{\mathrm{L}} \cdot T \cdot z^{-2}\right)\left(1-z^{-1}\right)}
$$

である（43)式に最終值の定理を用いると，

$$
\lim _{n \rightarrow \infty} \varepsilon(n T)=\lim _{z \rightarrow 1} \varepsilon^{*}(z) \cdot\left(1-z^{-1}\right)=A / K_{\mathrm{L}}
$$

となり，フリージャイロ方式，レートジャイロ方式の 場合と同様に一定の目視線角速度に対して定常偏差が 残る追尾装置になっている。したがって，ステップ入 力に対する (43)式の過渡応答においてオーバーシュー トがないことを仮定すれば、追尾が維持される条件は (18)式および(44)式加。

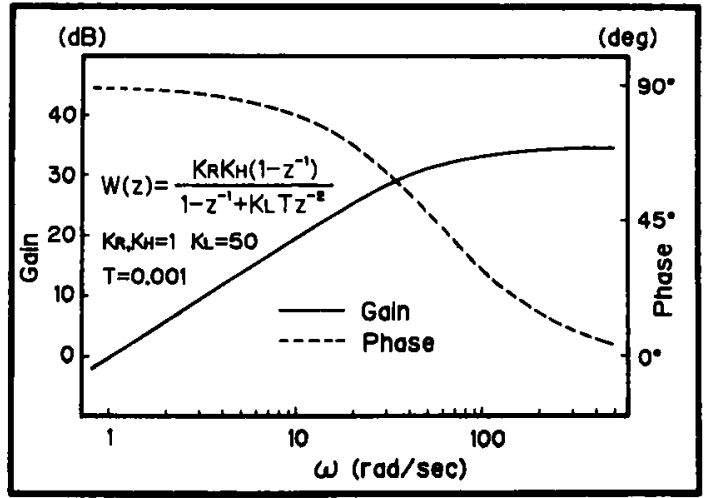

第 8 図 ストラップダウン方式目標追尾装置周波数応答 特性 


$$
\left|\frac{A}{K_{\mathrm{L}}}\right| \leq \varepsilon_{\max }
$$

であり，ストラップダウン方式の最大追尾角速度は，

$$
\dot{\lambda}_{\max } \leq \varepsilon_{\max } \cdot K_{\mathrm{L}}
$$

である

次にストラップダウン方式目標追尾装置の安定性に ついて考察する．特性方程式は(39)式より，

$$
z^{2}-z+K_{\mathrm{L}} T=0
$$

である.ここで， $z=(w+1) /(w-1)$ なる双 1 次変換 を行うと(47)式は，

$$
K_{\mathrm{L}} T w^{2}+2\left(1-K_{\mathrm{L}} T\right) w+K_{\mathrm{L}} T+2=0
$$

である（47)式が安定である条件は (48) 式の特性根の 実部が負であることである。したがって，

$$
0<K_{\mathrm{L}} T<1
$$

である，すなわち目標追尾装置としての目標追尾特 性，周波数応答特性を向上させるためにループゲイン $K_{\mathrm{L}}$ を大きくすると，それに応じてサンプルフレーム タイム $T$ を短くしなければならない。

空間安定特性：飛翔体回転角速度 $q(s)$ に対する目 標追尾装置の出力 $X_{0 \mathrm{oq}}(s)$ は (35)，(36) 式加ら，

$$
X_{0 \mathrm{q}}(s)=W(s)\left(K_{\mathrm{l}} e^{-\tau s}-1\right) \frac{1}{s} q(s)
$$

である．ここで $W(s)$ は(33)式で与えられる，したが って，(14)式の定義によればストラップダウン方式の 空間安定特性は,

$$
K_{\mathrm{s}}(\omega)=20 \log |W(j \omega)| \cdot \frac{\left|K_{1} e^{-j \omega T}-1\right|}{\omega}
$$

で与えられる。(50)式において $W(s)$ は，第 8 図から 設計に必要な低周波数領域では近似的に微分特性とみ ることができるから，

$$
K_{\mathrm{s}}(\omega) \fallingdotseq 20 \log \left|K_{1} e^{-j w \tau}-1\right|
$$

であり，Kが理想的に 1 の場合は,

$K_{\mathrm{s}}(\omega) \fallingdotseq 20 \log 2|\sin (\omega T / 2)|$

である.さらに $\omega T \ll 1 て ゙ は ，$

$$
K_{\mathrm{s}}(\omega) \div 20 \log \omega T
$$

である。

第 9 図に $K_{\mathrm{I}}=1$ としたときの $K_{\mathrm{s}}(\omega)$ をサンプルフ レームタイム $T$ が $1 \mathrm{~ms}$ と $10 \mathrm{~ms} の$ 場合について示 す 第 9 図および(54)式からわかるようにストラップ ダウン方式の場合の空間安定特性は, 目標追尾ループ に含まれる無駄時間（サンプルフレームタイム） $T$ て 決定される.ストラップダウン方式の場合もレートジ ヤイロ方式の場合と同様に，考虑すべきは飛翔体の最 大固有角周波数 $\omega_{\mathrm{a}}$ 以下の領域であり，その領域で (54) 式が誘導制御系設計上許容される $K_{\mathrm{s}}^{*}\left(\omega_{\mathfrak{a}}\right)$ 以下に なるようにサンプルフレームタイム $T$ が選定されな ければならない。

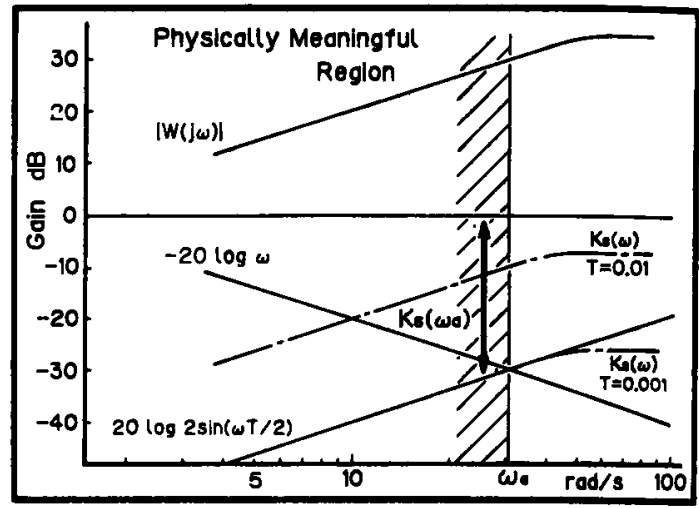

第 9 図 ストラップダウン方式目標追尾装置空間安定特性 ダイン線図

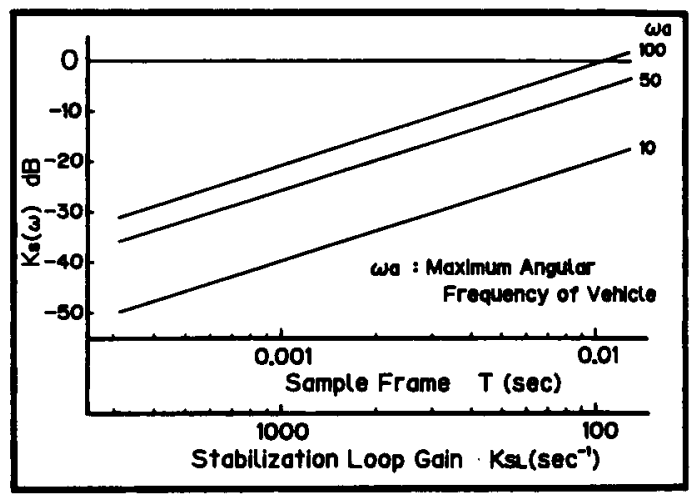

第 10 図 サンプルフレームタイムおよび空間安定化ルー プゲインと空間安定特性の咸係

以上の結果をレートジャイロ方式の場合と比較する と空間安定特性について，(30)式と(54)式から，

$$
T=1 / K_{\mathrm{sL}}
$$

の関係がある。第 10 図に飛翔体の最大固有振動数 $\omega_{\mathrm{B}}$ をパラメータにして、レートジャイロ方式の空間安定 化ループゲイン $K_{\mathrm{SL}}$ およびストラップダウン方式のサ ンプルフレームタイム $T$ に対する空間安定特性 $K_{\mathrm{s}}(\omega)$ の関係を示す．この図により飛翔体の最大固有 角周波数およびシステム設計上実現すべき空間安定特 性值から，目標追尾装置が満足すべき $K_{\mathrm{SL}}$ および $T$ を一義的に決定することができる．

\section{6. おわりに}

飛㓞体用目標追尾装置をフリージャイロ方式，レー トジャイロ方式，ストラップダウン方式の 3 方式に分 類し，各々について飛翊体運動との連成を考虑に入れ た動特性モデルを与えた．また目標迫尾装貫のモデル 不確定性には 2 種類の考え方が必要であることを示 
し，寄生ループを構成するモデル不確定性（空間安定 特性）については定量的な定義式を与えた。 また動特 性モデルを用いた基本性能解析を示すとともに，空間 安定特性という意味においてレートジャイロ方式の空 間安定化ループゲイン $K_{\mathrm{SL}}$ の逆数とストラップダウン 方式のサンプルフレームタイム $T$ とが一対一に対応 することを示した。なお，モデル不確定性を考虑にい れた誘導制御系のロバストな設計については，別の機 会に報告する予定である．

\section{参考文献}

1) Murtaugh, S. A. and Criel, H. E. : Fundamentals of Proportional Navigation, IEEE Spectrum, Dec. (1966), pp. 75-85.

2) Nesline, F. W., Jr. and Zarchan, P.: A New Look at Classical vs Modern Homing Guidance, J. Guid., 8 (1985), pp. 3-8.

3) Bryson, A. E. and Ho, Y. C. : Applied Optimal Control, Hemisphere Publishing Corp., 1975.

4) Wolfe, W. L. and Zissis, G. I.: The Infrared Handbook, Office of Naval Research Department of Navy, Arlington, VA., 1978.

5) Dow, R. B. : Fundamentals of Advanced Missiles, John Wiley \& Sons, Inc., 1958.
6) Merrill, G. : System Preliminary Design, D. Van Nostrand Company, Inc., 1960.

7) Nesline, F. W., Jr. and Zarchan, P.: Digital Homing Guidance-Stability vs Performance Trade-off, J. Guid., 8,2 (1985).

8) Nesline, F. W., Jr. and Zarchan, P.: Missile Guidance Design Tradeoffs for High-Altitude Air Defense, J. Guid., 6, 3 (1983).

9) Rue, A. K.: Stabilization of Precision Electro-Optical Pointing and Tracking Systems, IEEE, AES-5 (1969), pp. 805-819.

10) Rue, A. K.: Precision Stabilization Systems, IEEE, AES-10 (1974), pp. 34-42.

11) White, S. A.: Dynamics of a Solenoidal-Torqued GyroStabilized Seeker Assembly for Guidance and Tracking, IEEE, AES-10 (1974).

12) Willman, W. W. . Effects of Strapdown Seeker ScaleFactor Uncertainty on Optimal Guidance, J. Guid., 11, 3 (1988), pp. 199-206.

13) Vergez, P. L. and McClendon, J. R. : Optimal Control and Estimation for Strapdown Seeker Guidance of Tactical Missiles, J. Guid., 5, 3 (1982), pp. 225-226.

14) Doyle, J. C. and Stein, G. . Multivariable Feedback Design: Concepts for Classical/Modern Synthesis, IEEE, AC-26 (1981), pp. 4-16.

15）江口弘文, 渡辺惷司: 飛敖体用目標トラッキング装置の空 間安定性について、第 26 回飛行機シンポジウム請演集。 1988. 